\title{
Penerapan Model Pembelajaran Probing Prompting dalam Upaya Meningkatkan Hasil Belajar Siswa pada Tema Udara Bersih Bagi Kesehatan di Kelas V.A SD Negeri 114/X Pandan Jaya
}

\author{
Deby Utoyo \\ SD Negeri 114/X Pandan Jaya \\ J1. Hasanuddin, Pandan Jaya, Kec. Geragai, Kab. Tanjung Jabung Timur Prov. Jambi \\ Debyutoyo1880@gmail.com
}

\begin{abstract}
This study aims to disclose information and discuss the application of the Probing Prompting Learning Model in an Effort to Improve Student Learning Outcomes on the Theme of Clean Air for Health in Class V.A SD Negeri 114/X Pandan Jaya. This research is included in the type of classroom action research (CAR). This research was carried out in this research was carried out at SD Negeri 114/X Pandan Jaya. The time of this research was carried out in the odd semester of the 2021 - 2022 school year, which began in August 2021. The subjects in this study were 25 class V.A students. The research procedure consisted of two cycles with four stages of research starting from planning, implementing, observing and reflecting. Data collection in this study was carried out using observation sheets, field notes, learning outcomes test sheets, and documents. The data were analyzed using the percentage formula. The results of this study indicate that the Probing Prompting Learning Model on the Theme of Clean Air for Health can improve student learning outcomes in class VA SD Negeri 114/X Pandan Jaya which is marked by an increase from pre-cycle (20\%), cycle I (60\%), cycle II $(92 \%)$.
\end{abstract}

Keywords: Learning Outcomes, Probing Prompting Learning Model

\begin{abstract}
Abstrak
Penelitian ini bertujuan untuk mengungkapkan informasi dan membahas tentang Penerapan Model Pembelajaran Probing Prompting dalam Upaya Meningkatkan Hasil Belajar Siswa pada Tema Udara Bersih Bagi Kesehatan Di Kelas V.A SD Negeri 114/X Pandan Jaya. Penelitian ini termasuk dalam jenis penelitian tindakan kelas (PTK). Penelitian ini dilaksanakan di Penelitian ini dilaksanakan di SD Negeri 114/X Pandan Jaya. Waktu penelitian ini dilaksanakan pada semester ganjil tahun pelajaran 2021 - 2022, yang dimulai pada bulan Agustus 2021. Subjek dalam penelitian ini adalah siswa kelas V.A yang berjumlah 25 orang. Prosedur penelitian terdiri dari dua siklus dengan empat tahap peneletian mulai dari perencanaan, pelaksanaan, observasi dan refleksi. Pengumpulan data dalam penelitian ini dilakukan dengan menggunakan lembar observasi, catatan lapangan, lembar tes hasil belajar, dan dokumen. Data dianalisis dengan menggunakan rumus persentase. Hasil penelitian ini menunjukkan bahwa melalui Model Pembelajaran Probing Prompting pada Tema Udara Bersih bagi Kesehatan dapat meningkatkan hasil belajar siswa di kelas V.A SD Negeri 114/X Pandan Jaya yang ditandai oleh meningkatnya dari pra siklus (20\%), siklus I (60\%), siklus II (92\%).
\end{abstract}

Kata Kunci : Hasil Belajar, Model Pembelajaran Probing Prompting.

Copyright (c) 2021 Deby Utoyo

Corresponding author: Deby Utoyo

Email Address: debyutoyo1880@gmail.com (Jl. Hasanuddin, Pandan Jaya, Kec. Geragai, Jambi)

Received 01 December, Accepted 13 December 2021, Published 13 December 2021

\section{PENDAHULUAN}

Pemerintah telah berusaha untuk meningkatkan mutu pendidikan dengan berupaya kearah penyempurnaan kurikulum pendidikan KBK tahun 2004 menjadi KTSP tahun 2006 (Kurikulum Tingkat Satuan Pendidikan), menjadi Kurikulum 2013 (K13) dan sekarang menjadi KURNAS (Kurikulum Nasional) . Pendidikan ialah suatu usaha yang dengan sengaja dipilih untuk mempengaruhi dan membantu anak yang bertujuan untuk meningkatkan ilmu pengetahuan, jasmani 
dan akhlak sehingga secara perlahan bisa mengantarkan anak kepada tujuan dan cita-citanya yang paling tinggi (Prof. H. Mahmud Yunus).

Hal ini telah dicantumkan dalam UU no.2 tahun 2003 tentang (SISDIKNAS) yaitu Pendidikan merupakan suatu usaha yang dilakukan secara sadar dan terencana untuk mewujudkan suasana dan proses pembelajaran agar peserta didik secara aktif mampu mengembangkan potensi yang ada didalam dirinya. Semua siswa harus belajar dengan rajin dan sungguh-sungguh, mempunyai kemauan yang kuat untuk belajar dan mau melakukannya adalah modal dasar siswa untuk sukses. Agar belajar lebih berhasil maka siswa mempunyai perhatian yang baik dalam belajar, menguasai materi pelajaran. Selain itu dalam kegiatan belajar mengajar, guru dituntut untuk kreatif dalam melaksanakan suatu metode pembelajaran tertentu agar seluruh siswa dapat belajar dengan aktif dalam mengembangkan segala kemampuannya baik kognitif, afektif, maupun psikomotor sehingga segala potensi yang dimiliki dapat dikembangkan secara optimal. Penggunaan variasi model pembelajaran yang tepat dapat menimbulkan suasana yang menyenangkan dalam kelas dan juga dapat meningkatkan hasil belajar siswa.

Peran guru bergeser dari menentukan "apa yang akan dipelajari" ke "bagaimana menyediakan dan memperkaya pengalaman belajar siswa". Pengalaman belajar diperoleh melalui serangkaian kegiatan untuk mengeksplorasi lingkungan melalui interaksi aktif dengan teman, lingkungan, dan nara sumber lain. Telah dilakukan upaya-upaya peningkatan hasil dengan cara peningkatan fasilitasfasilitas penunjuang pembelajaran, memberikan contoh-contoh yang nyata kepada siswa agar mereka lebih paham lagi, guru telah memberikan berbagai macam cara agar siswa tersebut paham dengan materi yang diajarkan oleh guru.

Bedasarkan observasi dan pengalaman mengajar peneliti di SD Negeri 114/X Pandan Jaya Kabupaten Tanjung Jabung Timur khususnya siswa kelas V.A Dalam proses pembelajaran siswa masih belum serius dalam melihat guru menerangkan pelajaran, siswa banyak yang tidak fokus dan meribut selama proses pembelajaran berlangsung, sehingga berpengaruh langsung terhadap hasil belajar siswa. Hal ini didapatkan dari hasil nilai ulangan harian siswa yang belum menvapai target pembelajaran.

Salah satu upaya pemecahannya adalah dengan menggunakan model pembelajaran probing prompting. Menurut Hamdani (2011, hlm. 23), pembelajaran probing prompting adalah pembelajaran dengan menyajikan serangkaian pertanyaan yang sifatnya menuntun dan menggali gagasan siswa sehingga dapat melejitkan proses berpikir yang mampu mengaitkan pengetahuan dan pengalaman siswa dengan pengetahuan baru yang sedang dipelajari.

Penelitian ini bertujuan untuk mengungkapkan informasi dan membahas tentang Penerapan Model Pembelajaran Probing Prompting Dalam Upaya Meningkatkan Hasil Belajar Siswa Pada Tema Udara Bersih Bagi Kesehatan Di Kelas V.A SD Negeri 114/X Pandan Jaya. Menurut Trianto (2012:17) Belajar adalah sebagai proses perubahan perilaku tetap dari belum tahu menjadi tahu, dari tidak paham menjadi paham, dari kurang terampil menjadi terampil, dan dari kebiasaan lama menjadi 
kebiasaan baru, serta bermanfaat bagi lingkungan maupun individu itu sendiri. Menurut Slameto (2010:2) Belajar ialah suatu proses usaha yang dilakukan seseorang untuk memperoleh suatu perubahan tingkah laku yang baru secara keseluruhan, sebagai hasil pengalamannya sendiri dalam interaksi dengan lingkunganya.

Menurut Pribady (2011:6) Belajar adalah kegiatan yang dilakukan oleh seseorang agar memiliki kompetensi berupa keterampilan dan pengetahuan yang di perlukan. Belajar juga dapat dipandang sebagai sebuah proses elaborasi dalam upaya pencarian makna yang dilakukan oleh individu. Proses belajar pada dasarnya di lakukan untuk meningkatkan kemampuan atau kompetensi personal.

Menurut Suprijono (2012:3) Belajar sebagi konsep mendapatkan pengetahuan dalam praktiknya banyak dianut. Guru bertindak sebagai pengajar yang berusaha memberikan ilmu pengetahuan sebanyak-banyaknya dan peserta didik giat mengumpulkan atau menerimanya. Menurut Suryono dkk (2012:9) Belajar adalah suatu aktivitas atau memperoleh, pengetahuan, meningkatkan keterampilan, memperbaiki perilaku, sikap dan mengokohkan kepribadian.

Dari uraian di atas dapat disimpulkan bahwa belajar merupakan suatu proses yang terjadi dalam diri seseorang baik secara internal maupun eksternal yang dapat merubah pola prilaku maupun tingkah laku seseorang.

Menurut pemikiran Gagne dalam Agus Suprijono (2012:5-6) Hasil belajar berupa informasi verbal, keterampilan intelektual, strategi kognitif, keterampilan motorik, sikap. Menurut Bloom dalam Agus Suprijono (2012:6) Hasil belajar mencakup kemampuan kognitif, afektif, dan psikomotor. Menurut Suprijono (2012:5) Hasil belajar adalah pola-pola perbuatan, nilai-nilai, pengertianpengertian, sikap-sikap, dan apresiasi dan keterampilan.

Menurut Uno (2011:21) Hasil belajar adalah variable metode dan kondisi pembelajaran, variable hasil pembelajaran juga dapat diklasifikasikan dengan cara yang sama, pada tingkat yang amat umum sekali hasil pembelajaran dapat diklasifikasikan menjadi 3 (tiga) yaitu keefektifan, efesisensi, daya tarik. Dari uraian diatas dapat disimpulkan hasil belajar adalah perubahan perilaku secara keseluruhan berupa kemampuan kognitif, afektif, keterampilan, daya tarik, apresiasi dan informasi-informasi verbal.

Menurut Soekarno (Nurulwati, 2000:10) dalam Aris Shoimin (2014: 23) mengemukakan maksud dari model pembelajaran adalah kerangka konseptual yang melukiskan prosedur yang sistematis dalam mengorganisasikan pengalaman belajar untuk mencapai tujuan belajar tertentu, dan berfungsi sebagai pedoman bagi para perancang pembelajaran dan para pengajar dalam merencanakan aktivitas belajar mengajar.

Menurut Trianto (2012:15) mengatakan Pembelajaran merupakan aspek kegiatan manusia yang kompleks, yang tidak sepenuhnya dapat dijelaskan. Pembelajaran secara simpel dapat diartikan sebagai produk interaksi berkelanjutan antara pengembangan dan pengalaman hidup. Dalam makna yang lebih kompleks pembelajaran hakikatnya adalah sadar dari seseorang guru untuk membelajarkan 
siswanya (mengarahkan interaksi siswa dengan sumber belajar lainnya) dalam rangka mencapai tujuan yang diharapkan.

Dari uraian di atas dapat disimpulkan bahwa model pembelajaran adalah keterampilan komunikasi dalam berbagai konteks komunikasi. Kemampuan yang dikembangkan adalah daya tangkap makna, peran, daya tafsir, menilai, dan mengekspresikan diri dengan berbahasa dan suatu rencana mengajar yang digunakan sebagai pedoman dalam pembelajaran di kelas maupun tutorial.

Berdasarkan arti katanya, probing berarti menyelidiki, dan prompting berarti menuntun. Menurut Hamdani (2011, hlm. 23), pembelajaran probing prompting adalah pembelajaran dengan menyajikan serangkaian pertanyaan yang sifatnya menuntun dan menggali gagasan siswa sehingga dapat melejitkan proses berpikir yang mampu mengaitkan pengetahuan dan pengalaman siswa dengan pengetahuan baru yang sedang dipelajari.

Model pembelajaran probing prompting sangat berkaitan dengan pertanyaan. Dalam pembelajaran probing prompting ini pendididk mengajukan pertanyaan kepada siswa yang sifatnya menggali pengetahuan siswa dan menuntun siswa untuk mengaitkan pengetahuan baru yang didapatkan dengan pengetahuan yang telah diperolehnya. Dalam pembelajaran probing prompting terdapat dua bentuk pertanyaan, yaitu probing question dan prompting question. Mayasari (2014, hlm.1357) mengutip pendapat Suherman mengenai probing question dan prompting question, yaitu sebagai berikut. Probing question adalah pertanyaan yang bersifat menggali untuk mendapatkan jawaban yang lebih lanjut dari siswa yang bermaksud mengembangkan kualitas jawaban, sehingga jawaban berikutnya lebih jelas, akurat serta lebih beralasan, sedangkan prompting question, pertanyaan ini bermaksud untuk menuntun siswa agar ia dapat menemukan jawaban yang lebih benar.

Menurut Suyatno (Swarjawa, 2013, hlm. 84) "Praktik pembelajaran menggunakan probing prompting disajikan melalui serangkaian pertanyaan-pertanyaan yang menggali pengetahuan siswa serta membimbing ke arah perkembangan yang diharapkan". Dalam pembelajaran probing prompting guru secara mendadak menunjuk siswa secara acak untuk menjawab pertanyaan yang diajukan. Karena proses tanya jawab yang secara tiba-tiba dengan menunjuk siswa secara acak sehingga setiap siswa mau tidak mau harus selalu berkonsentrasi dalam pembelajaran, siswa tidak bisa menghindar dari proses pembelajaran, setiap saat ia bisa dilibatkan dalam proses tanya jawab.

Hal tersebut membuat siswa untuk selalu fokus terhadap kegiatan pembelajaran karena mau tidak mau siswa suatu saat akan diajukan pertanyaan oleh guru dan harus menjawabnya. Kemungkinan akan terjadi suasana tegang, namun bisa diatasi jika dibiasakan. Untuk mengurangi kondisi tegang tersebut, saat mengajukan pertanyaan guru hendaknya bersikap ramah kepada siswa serta menghargai setiap jawaban siswa. Jika jawaban siswa salah guru sebaiknya menuntun siswa tersebut menuju jawaban yang benar bukan malah merendahkan dan menyudutkannya didepan siswa yang lain. 


\section{METODE}

Penelitian ini termasuk dalam jenis penelitian tindakan kelas (PTK). Penelitian ini dilaksanakan di Penelitian ini dilaksanakan di SD Negeri 114/X Pandan Jaya. Waktu penelitian ini dilaksanakan pada semester ganjil tahun pelajaran 2021 - 2022, yang dimulai pada bulan Agustus 2021. Subjek dalam penelitian ini adalah siswa kelas V.A yang berjumlah 25 orang. Prosedur penelitian terdiri dari dua siklus dengan empat tahap peneletian mulai dari perencanaan, pelaksanaan, observasi dan refleksi. Pengumpulan data dalam penelitian ini dilakukan dengan menggunakan lembar observasi, catatan lapangan, lembar tes hasil belajar, dan dokumen. Data dianalisis dengan menggunakan rumus persentase.

\section{HASIL DAN DISKUSI}

\section{Paparan Pra Siklus}

Pra siklus merupakan kondisi awal siswa sebelum peneliti melakukan kegiatan penelitian di dalam kelas, dengan menggunakan pola pembelajaran konvensional. Selanjutnya, berdasarkan hasil data pra siklus yang diperoleh, peneliti bersama guru lain melakukan evaluasi mengenai metode/model pembelajaran yang dianggap tepat, sebagai bentuk tindakan perbaikan dari proses pembelajaran. Kegiatan pengambilan data pra siklus dilakukan di kelas V.A dengan jumlah siswa 25 orang. Pra siklus dilakukan peneliti dengan cara melaksanakan kegiatan pembelajaran dengan menggunakan metode pembelajaran yang banyak didominasi oleh guru yang diakhiri dengan pelaksanaan tes.

Hasil proses pembelajaran terlihat monoton dan berpusat pada guru, tingkat partisipasi siswa dalam belajar rendah, kurang termotivasi dalam belajar, banyak siswa yang tidak memperhatikan ketika guru menerangkan pelajaran di depan kelas, dan mengobrol bersama temannya, serta kurang paham nya siswa saat melakukan tugas yang diberikan oleh guru, sehingga membuat nilai atau hasil belajarnya rendah. Dampaknya hasil belajar siswa juga rendah, ini dibuktikan dari hasil ulangan harian terakhir sebelum metode yang diterapkan, untuk lebih jelasnya dapat dilihat pada tabel di bawah ini:

Tabel 1. Rekapitulasi Hasil Belajar Siswa Pra Siklus

\begin{tabular}{|l|c|}
\hline Jumlah Nilai & 1630 \\
\hline Rata - Rata & 65,20 \\
\hline KKM & 67 \\
\hline Jumlah Siswa Yang Tuntas & 5 Orang / 20\% \\
\hline Jumlah Siswa Yang Belum Tuntas & 20 Orang / 80\% \\
\hline
\end{tabular}

Dari tabel di atas dapat dijelaskan bahwa sebelum menerapkan model pembelajaran probing prompting di peroleh rata - rata hasil belajar siswa yaitu 65,20 dengan presentase $20 \%$ atau 5 orang dari 25 siswa yang tuntas belajar. Hasil tersebut menunjukkan bahwa pada pra siklus secara klasikal 
siswa belum tuntas belajar, karena hanya 5 siswa yang memperoleh nilai $\geq 67$ atau hanya sebesar $20 \%$ yang mencapai kriteria ketuntasan minimum (KKM).

Sehingga, masih terdapat 20 dari 25 orang yang belum tuntas belajar atau sebanyak $80 \%$. Hasil tersebut lebih kecil dari presentase ketuntasan klasikal dalam proses pembelajaran yang dikehendaki sebesar $80 \%$ siswa yang tuntas. Berdasarkan tabel nilai dan penjelasan nilai pra siklus diatas dapat dilihat lebih jelas pada diagram dibawah ini:

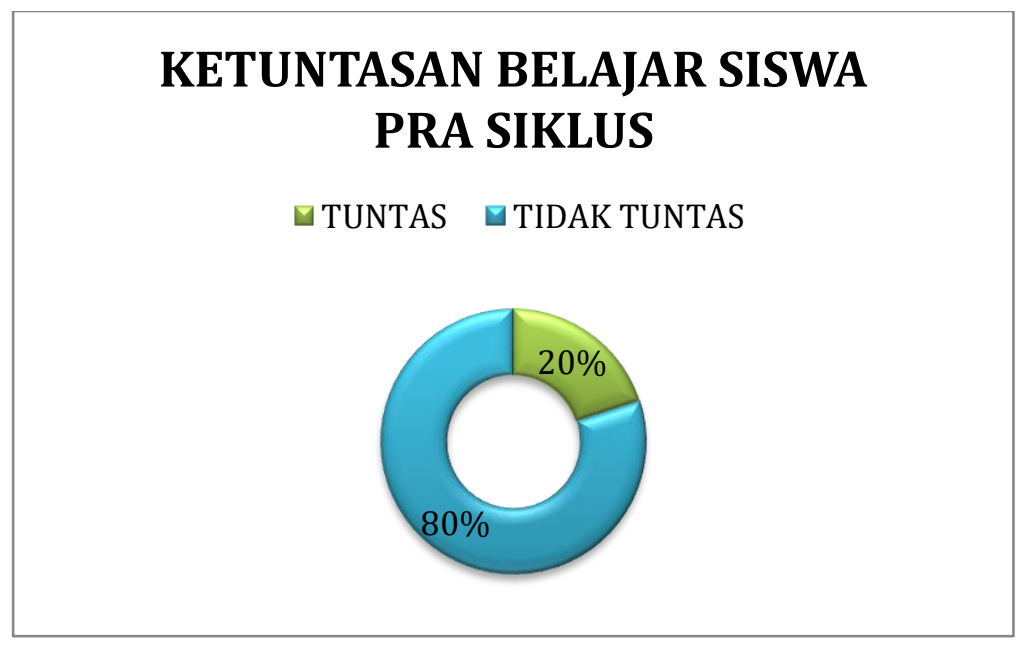

Gambar 1. Ketuntasan Hasil Belajar Siswa Pra Siklus

Berdasarkan kenyataan di atas, peneliti dibantu oleh teman sejawat (Yetty, S.Pd) melakukan kajian dan telah yang akan dipergunakan sebagai dasar pertimbangan memilih strategi pembelajaran yang tepat, dalam upaya melakukan tindakan perbaikan pembelajaran. Setelah mempertimbangkan berbagai alasan tersebut, peneliti memilih model pembelajaran probing prompting. Model ini dipergunakan dalam PTK yang akan dilaksanakan pada saat berlangsungnya proses pembelajaran di Kelas V.A SD Negeri 114/X Pandan Jaya, yang diharapkan dapat meningkatkan hasil belajar siswa.

\section{Hasil Penelitian}

\section{Siklus I}

\section{Tahap Perencanaan}

Sebelum melakukan pengumpulan data berupa kegiatan pembelajaran, peneliti terlebih dahulu menyusun perencanaan kegiatan yang meliputi:

a. Mempersiapkan jadwal penelitian tindakan kelas

b. Merencanakan materi yang akan dilaksanakan pada waktu penelitian agar mengetahui kompetensi dasar yang akan disampaikan kepada siswa dalam pembelajaran

c. Mempersiapkan RPP

d. Mempersiapkan silabus, LKS, instrumen

e. Mempersiapkan media pembelajaran yang dibutuhkan

\section{Tahap Pelaksanaan}

Pelaksanaan siklus I pertemuan pertama pada hari Senin tanggal 16 Agustus 2021 pada jam pelajaran 3-4 di kelas V.A dengan jumlah siswa 25 orang. Adapun tema pembelajaran adalah Udara 
Bersih Bagi Kesehatan. Prosedur penelitian sesuai dengan yang ada pada rencana pelaksanaan pembelajaran mulai dari kegiatan pendahuluan, kegiatan inti dan penutup.

Pelaksanaan siklus I pertemuan kedua pada hari senin tanggal 19 Agustus 2021 di kelas V.A pada jam pelajaran 3-4 dengan jumlah siswa 25 orang. Adapun tema pembelajaran pada pertemuan kedua ini adalah udara bersih bagi kesehatan. Prosedur penelitian sesuai dengan rencana pelaksanaan pembelajaran yang ditentukan mulai dari kegiatan pendahuluan, kegiatan inti dan kegiatan penutup.

\section{Observasi}

Pengamatan dilaksanakan bersamaan dengan pelaksaaan belajar mengajar yang dilakukan oleh observer. Adapun yang diamati oleh Observer meliputi pengelolaan belajar mengajar guru, aktivitas guru dan aktivitas siswa selama proses pembelajaran. Pada akhir proses belajar mengajar siswa diberi tes formatif dengan tujuan untuk mengetahui tingkat keberhasilan siswa dalam proses belajar mengajar yang telah dilakukan. Adapun data hasil penelitian pada siklus I adalah sebagai berikut:

Tabel 2. Rekapitulasi Hasil Belajar Siswa Siklus I

\begin{tabular}{|l|c|}
\hline Jumlah Nilai & 1826 \\
\hline Rata -Rata & 73,04 \\
\hline Kkm & 67 \\
\hline Jumlah Siswa Yang Tuntas & 15 Orang / 60\% \\
\hline Jumlah Siswa Yang Belum Tuntas & 10 Orang / 40\% \\
\hline
\end{tabular}

Dari tabel di atas dapat dijelaskan bahwa dengan menerapkan pembelajaran dengan model pembelajaran probing prompting, diperoleh rata-rata hasil belajar siswa 73,04 dengan jumlah siswa yang tuntas sebanyak 15 orang dengan persentase $60 \%$ dan siswa yang tidak tuntas sebanyak 10 orang dengan persentase $40 \%$. Selanjutnya Hasil tersebut menunjukkan bahwa pada siklus pertama secara klasikal siswa belum tuntas belajar, karena siswa yang memperoleh nilai $\geq 67$ hanya sebesar $60 \%$ lebih kecil dari persentase ketuntasan yang dikehendaki yaitu sebesar $80 \%$. Hal ini disebabkan karena siswa masih belum bisa menyesuaikan diri dengan pokok bahasan materi yang disampaikan melalui model pembelajaran probing prompting, tersebut. Untuk lebih jelasnya mengenai hasil belajar siswa pada sikluls I ini dapat dilihat gambar diagram ketuntasan belajar dibawah ini: 


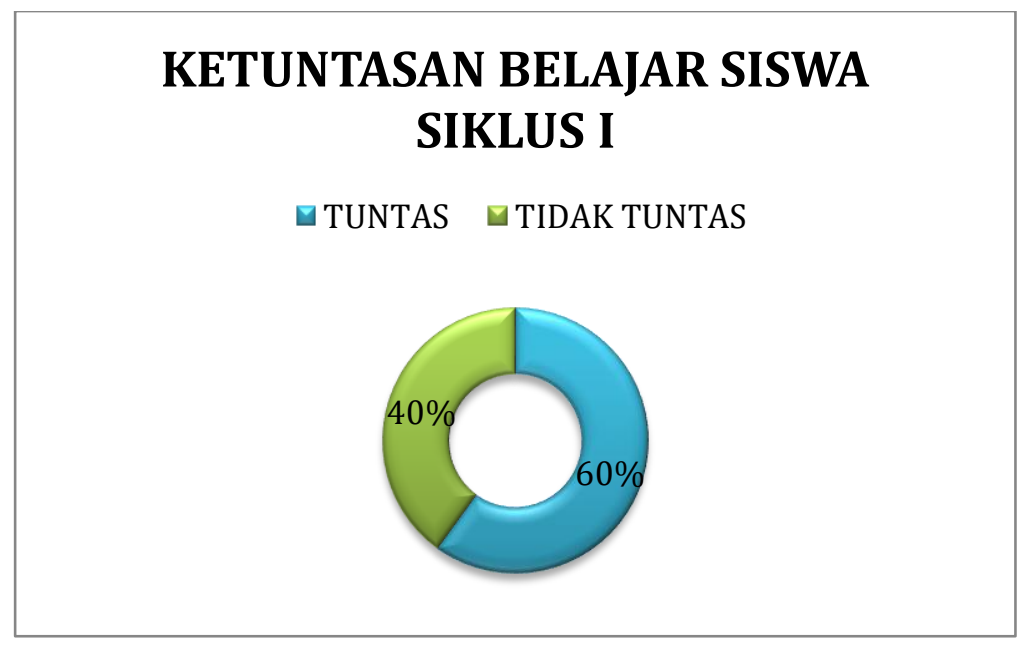

Gambar 2. Ketuntasan Hasil Belajar Siswa Siklus I

\section{Refleksi}

Berdasarkan hasil pengamatan observer serta diskusi yang di lakukan di ruang majelis guru terhadap kegiatan belajar mengajar yang dilakukan oleh peneliti pada siklus I, dapat disimpulkan: 1) Memotivasi siswa masih lemah. 2) Kurang terkontrol dalam mengawasi setiap kelompok secara bergiliran. 3) Kelompok-kelompok belajar kurang heterogen. 4) Kurang baik dalam memberikan evaluasi. 5) Kurang baik dalam pengelolaan waktu. 6) Siswa kurang antusias dalam belajar.

Berdasarkan temuan pada siklus I diatas, maka untuk mengantisispasi supaya tidak terjadi pada pertemuan berikutnya, maka perlu dilakukan evaluasi dengan merencanakan: 1) Memberikan motivasi yang kuat terhadap siswa. 2) Mengawasi kelompom dalam bekerja. 3) Membagi kelompok secara heterogen. 4) Memberikan evaluasi yang baik lagi. 5) Mengelola waktu dengan baik dan 6) Menyiapkan rewort untuk kelompok yang memiliki antusias serta nilai yang tinggi.

\section{Siklus II}

\section{Tahap Perencanaan}

Tahap perencanaan dalam siklus II ini adalah menyusun RPP, menyusun lembar pengamatan, menyiapkan media pendukung pembelajaran, membuat instrumen beserta jawaban, menyiapkan alat dan menyiapkan LKS.

\section{Tahap Pelaksanaan}

Pelaksanaan siklus II pertemuan pertama pada hari Senin tanggal 23 Agustus 2021 jam pelajaran 3-4 di kelas V.A dengan jumlah siswa 25 orang. Adapun tema pembelajaran pada pertemuan pertama ini adalah udara bersih bagi kesehatan. Prosedur penelitian sesuai dengan rencana pelaksanaan pembelajaran yang ditentukan mulai dari kegiatan pendahuluan, kegiatan inti dan kegiatan penutup.

Pelaksanaan pertemuan kedua pada hari rabu tanggal 25 Agustus 2021 di kelas V.A jam pelajaran 3-4 dengan jumlah siswa 25 orang. Adapun tema pembelajaran pada pertemuan pertama ini adalah udara bersih bagi kesehatan. Prosedur penelitian sesuai dengan rencana pelaksanaan pembelajaran mulai dari kegiatan pendahuluan, kegiatan inti dan kegiatan penutup. 


\section{Observasi}

Kegiatan Pengamatan atau Observasi dilaksanakan bersamaan dengan pelaksanaan belajar mengajar. Kegiatan Observasi oleh Observer dilakukan selama peneliti melaksanakan kegiatan proses belajar mengajar. Adapun yang diamati oleh Observer meliputi pengelolaan belajar mengajar guru, aktivitas guru dan aktivitas siswa selama proses pembelajaran.

Selain itu, pada setiap akhir proses belajar mengajar siswa akan diberikan tes, dengan tujuan untuk mengukur sejauh mana tingkat keberhasilan peneliti dalam melaksanakan proses pembelajaran. Berikut hasil tes siswa pada siklus II dapat dilihat jelas pada tabel berikut:

Tabel 3. Rekapitulasi Hasil Belajar Siswa Siklus II

\begin{tabular}{|l|c|}
\hline Jumlah & 2013 \\
\hline Rata -Rata & 80,53 \\
\hline KKM & 67 \\
\hline Jumlah Siswa Yang Tuntas & 23 Orang / 92\% \\
\hline Jumlah Siswa Yang Belum Tuntas & 2 Orang / 8\% \\
\hline
\end{tabular}

Dari tabel siklus II diatas, terlihat bahwa hasil belajar siswa mengalami peningkatan yang lebih baik dari siklus I. Hasil rata-rata nilai yang diperoleh siswa pada siklus II ini sebesar 80,53 yakni dari 25 siswa sebanyak 23 orang pada siklus II ini sudah berhasil mendapat nilai yang baik yakni $\geq 67$ dengan ketuntasan belajar mencapai $92 \%$ Hal ini menunjukkan bahwa pada siklus II secara klasikal siswa telah tuntas belajar, karena siswa yang memperoleh nilai $\geq 67$ telah meningkat sebanyak $92 \%$ lebih besar dari persentase ketuntasan yang dikehendaki yaitu sebesar $80 \%$.

Dari data tersebut dapat disimpulkan bahwa adanya peningkatan hasil belajar pada siklus II ini dapat terjadi karena guru selalu menginformasikan bahwa setiap akhir pelajaran akan selalu diadakan tes sehingga pada pertemuan berikutnya siswa lebih siap dan termotivasi untuk belajar. Selain itu juga terjadi peningkatan kemampuan guru dalam menerapkan model pembelajaran probing prompting, sehingga membuat siswa menjadi lebih terbiasa dengan pembelajaran menggunakan model pembelajaran probing prompting. Hal ini akan berpengaruh baik terhadap peningkatan hasil belajar. Untuk lebih jelasnya dapat dilihat tabel ketuntasan hasil belajar dibawah ini: 


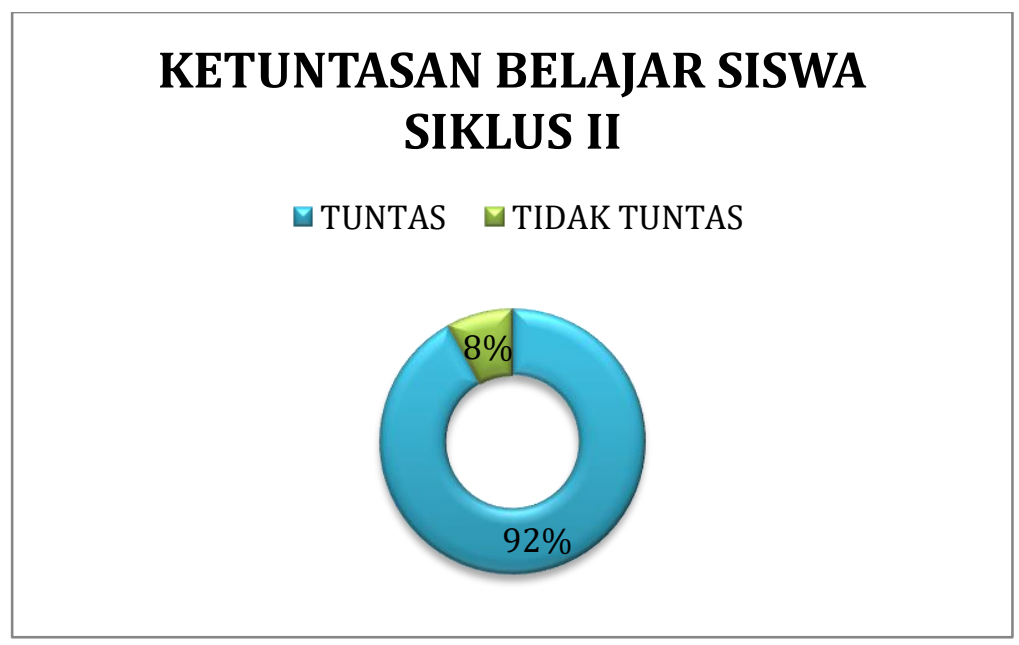

Gambar 3. Ketuntasan Hasil Belajar Siswa Siklus II

\section{Refleksi}

Pada tahap ini akan dikaji apa yang telah terlaksana dengan baik maupun yang masih kurang baik dalam proses belajar mengajar dengan penerapan belajar aktif. Berdasarkan hasil diskusi yang telah dilakukan dengan observer diruang majelis guru. Dari data-data yang telah diperoleh selama proses pembelajaran menggunakan model pembelajaran probing prompting, dapat diuraikan sebagai berikut: 1) Selama proses belajar mengajar guru telah melaksanakan semua pembelajaran dengan baik. Meskipun ada beberapa aspek yang belum sempurna, tetapi persentase peningkatan pelaksanaannya untuk masing-masing aspek cukup besar. 2) Berdasarkan data hasil pengamatan diketahui bahwa dalam setiap pertemuan, siswa semakin meningkat keaktifannya selama proses belajar berlangsung. 3) Kekurangan pada siklus-siklus sebelumnya sudah mengalami perbaikan dan peningkatan sehingga menjadi lebih baik. 4) Hasil belajar siswa pada siklus II telah berhasil mencapai ketuntasan.

\section{Diskusi}

Melalui hasil penelitian ini, menunjukkan bahwa pembelajaran dengan model pembelajaran probing prompting, memiliki dampak positif dalam meningkatkan hasil belajar siswa. Hal ini dapat dilihat dari semakin mantapnya pemahaman dan penguasaan siswa terhadap materi yang telah disampaikan guru pada setiap pelaksanaan siklus. Ketuntasan belajar meningkat mulai dari pra siklus, siklus I, dan siklus II yaitu masing-masing 20\%, 60\% dan 92\%. Pada siklus II ketuntasan belajar siswa secara klasikal telah tercapai dan mengalami peningkatan yang sangat baik.

Dari data tersebut dapat disimpulkan bahwa adanya peningkatan hasil belajar pada siklus II ini dapat terjadi karena guru selalu menginformasikan bahwa setiap akhir pelajaran akan selalu diadakan tes sehingga pada pertemuan berikutnya siswa lebih siap dan termotivasi untuk belajar. Selain itu juga terjadi peningkatan kemampuan guru dalam menerapkan model pembelajaran probing prompting, sehingga membuat siswa menjadi lebih terbiasa dengan pembelajaran menggunakan model pembelajaran probing prompting. Hal ini akan berpengaruh baik terhadap peningkatan hasil belajar. Untuk lebih jelasnya dapat dilihat gambar dibawah ini: 


\section{PENINGKATAN KETUNTASAN BELAJAR SISWA}

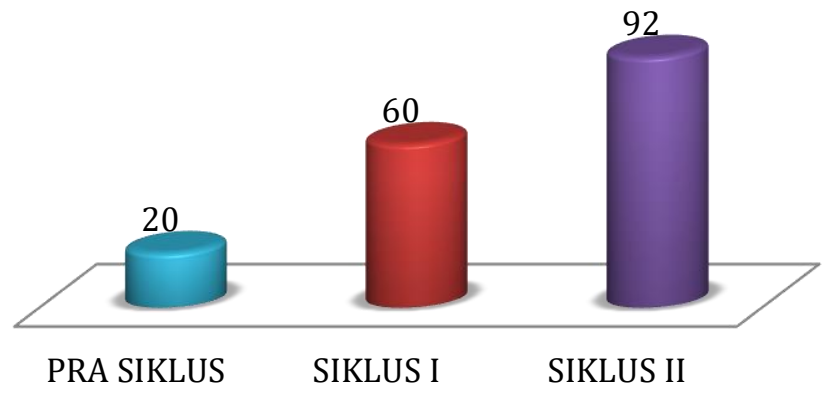

Gambar 4. Peningkatan Ketuntasan Hasil Belajar Siswa

\section{KESIMPULAN}

Dari hasil kegiatan pembelajaran yang telah dilakukan selama dua siklus, dan berdasarkan seluruh pembahasan serta analisis yang telah dilakukan dapat disimpulkan sebagai berikut:

1. Pembelajaran dengan menggunakan model pembelajaran probing prompting, memiliki dampak positif dalam meningkatkan hasil belajar siswa yang ditandai dengan peningkatan ketuntasan belajar siswa dalam setiap siklus, yaitu pra siklus (20\%), siklus I (60\%), siklus II (92\%).

2. Penerapan model pembelajaran probing prompting, mempunyai pengaruh positif, yaitu dapat meningkatkan hasil belajar siswa yang ditunjukan dengan rata-rata jawaban siswa yang menyatakan bahwa siswa tertarik dan berminat dengan model pembelajaran probing prompting, sehingga mereka menjadi termotivasi untuk belajar.

Dari hasil penelitian yang diperoleh dari uraian sebelumnya agar proses belajar pembelajaran lebih efektif dan lebih memberikan hasil yang optimal bagi siswa, maka disampaikan saran sebagai berikut:

1. Untuk melaksanakan model pembelajaran probing prompting, memerlukan persiapan yang cukup matang, sehingga guru harus mempu menentukan atau memilih topik yang benar-benar bisa diterapkan dengan model pembelajaran probing prompting, dalam proses belajar mengajar sehingga diperoleh hasil yang optimal.

2. Dalam rangka meningkatkan hasil belajar siswa, guru hendaknya lebih sering melatih siswa dengan berbagai metode pengajaran, walau dalam taraf yang sederhana, dimana siswa nantinya dapat menemukan pengetahuan baru, memperoleh konsep dan keterampilan, sehingga siswa berhasil atau mampu memecahkan masalah-masalah yang dihadapinya.

3. Perlu adanya penelitian yang lebih lanjut, karena hasil penelitian ini hanya dilakukan di SD Negeri 114/X Pandan Jaya tahun pelajaran 2021 - 2022.

4. Untuk penelitian yang serupa hendaknya dilakukan perbaikan-perbaikan agar diperoleh hasil yang lebih baik. 


\section{REFERENSI}

Adesty, M., Nurhanurawati., dan Widyastuti. 2014. "Pengaruh Model Pembelajaran Kooperatif Tipe NHT terhadap Kemampuan Komunikasi Matematis dan Belief." Jurnal Pendidikan Matematika Unila, Vol 2, No 2. Diakses pada tanggal 20 September 2017. (http://jurnal.fkip.unila.ac.id/index.php/MTK/ article/view/4309).

Agus, Suprijono. 2012. Cooperative Learning: Teori dan Aplikasi Paikem. Yogyakrta: Pustaka Pelajar.

Arikunto, Suharsimi. (2005). Manajemen Penelitian. Jakarta: Rineka Cipta.

Erman, Suherman. 2008. "Model Belajar dan Pembelajaran Berorientasi Kompetensi Siswa". http://pkab.wordpress.com/2008/04/29/. Diakses pada 4 November 2009.

Hamdani. 2011. Strategi Belajar Mengajar. Bandung : Pustaka Setia.

Kemmis and Taggart. (2002). The Action Research Planner. Victorio. Deakin. Univ Press.

Mayasari, Yuriska, dkk. 2014. Penerapan Teknik Probing Prompting dalam Pembelajaran Matematika Siswa Kelas VIII MTsN Lubuk Buaya Padang. Jurnal pendidikan Matematika FMIPA UNP. Vol. 3 No 1.

Nurulwati. (2000). Model-Model Pembelajaran. Surabaya: Universitas Negeri Surabaya.

Pribadi, Benny A. 2011. Model Desain Assure untuk Mendesain Pembelajaran Sukses. Jakarta: Dian Rakyat.

Rusman, 2012. Model-model Pembelajaran: Mengembangkan Profesionalisme Guru, RajaGrafindo Persada, Jakarta.

Shoimin, Aris. 2014. 68 Model Pembelajaran INOVATIF dalam Kurikulum 2013. Yogyakarta: ARRUZZ MEDIA.

Slameto. (2003). Belajar dan Faktor-faktor yang mempengaruhinya. Jakarta: Rineka Cipta.

Slameto. 2010. Belajar dan faktor-faktor yang Mempengaruhinya. Jakarta: PT. Rineka Cipta.

Suryono dan Hariyanto. (2012). Belajar dan Pembelajaran. Bandung: Remaja Rosdakarya.

Swarjawa, I.W.E. (2013). Pengaruh Model Pembelajaran Probing-Prompting Terhadap Hasil Belajar IPA Siswa Kelas V di SdD Negeri 1 Sebatu. MIMBAR PGSD, 1.

Trianto. 2010. Model Pembelajaran Terpadu, Konsep, Strategi dan Implementasinya dalam KTSP. Jakarta: Bumi Aksara.

Trianto. 2012. Model Pembelajaran Terpadu. (Jakarta: PT Bumi Aksara).

Uno B. Hamzah, 2011. Teori Motivasi dan Pengukurannya Analisis di Bidang Pendidikan. Jakarta: PT. Bumi Aksara

UU no. 2 tahun 2003 